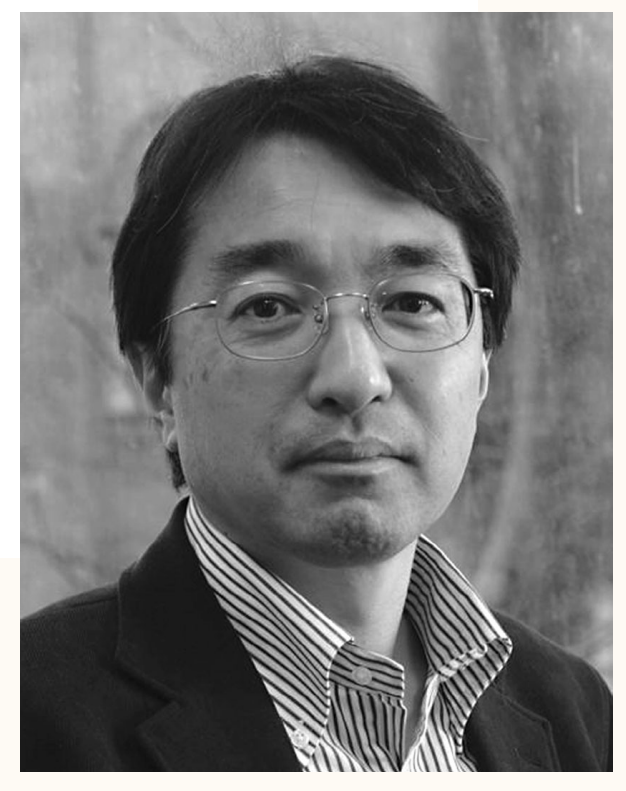

\title{
映像情報メディア学会誌 について
}

\section{相 澤 清 晴}

東京大学 大学院 情報理工学研究科

このたび, 皆様のご推挙を頂き, 映像情報メディア学 会の編集長を仰せつかりました。本会は，1933年から始 まったと伺っています。そのように伝統ある学会の活動 の集約である “学会誌” のとりまとめにたずさわるという 大役であり, 大変, 光栄に存じますとともに, 責任を感 じております.

私は，本会がテレビジョン学会と称していた時期, 博 士課程に進学した直後に会員になりました。最初は,「高 能率符号化」の論文特集に論文を投稿し出版するために, 学生会員になりました。本学会誌は, 会員へ向けた特集 記事と論文をすべて一体化した作りになっているため, 映像関係技術の多様な情報取得に適しており，以来， 20 年以上の長きにわたり, 会員であります. 他の多くの学 会と異なり，一般会誌と論文誌とを分けずに両者を合わ せてすべてが一つになっている学会誌を作っていること は，映情学誌の大きな特徴の一つであると思います.

その 20 年の間に, テレビジョン学会と称していた名称 も, より広い層への波及を求めて映像情報メディア学会 と変わりました. また, 映像が, ディジタルカメラやム ービーのおかげで一般に広く浸透しました. YouTube, Flickrに代表されるインターネット上での画像共有も進 みました，近く，インターネットのトラヒックの $80 \%$ は 映像になるともいわれ，“映像”や“メディア”の技術がま すます重要になっています. 研究そのものも高価な機材 に頼らずとも可能となり, 映像関係の研究者の層は, 大 学でも，大きく広がったように思います．映像が中心の マルチメディア関係の国際会議も多くできています.

学会にとっての “コア”となる部分が何かを考えてみる と, テレビジョン学会と称していた時には, “テレビ技術” という明確なコアがありました。急速に広がった映像を
背景に, 新しい展開を求めて, 映像情報メディア学会と 改称したのは, 英断を要したと思いますが, 現時点で見 れば，自然な成り行きといえると思います，ただし，ス コープを広げた一方で, 何がコアなのか見えにくくなっ ているようにも思えます。映像技術のスコープの広がり とともに, コアは増えているはずです，分野に対しての 認識を共有し, 現在の課題を明確にさせていくことは, 学会誌の使命であると思います. もともと, 本会はテレ ビジョンから始まったため, 放送映像の制作に関わる分 野も擁しています. 映像のコンテンツを作るための技術 に関しての第一の学会です.コンテンッは, 技術だけで なく, アートやデザイン, エンタテインメント, インタ ラクティブシステム, 心理, 知覚など本来高度な複合領 域です (なお, 知覚等の一部はすでに研究会での対象で もあります)。これらの広がる展開の中から生まれる新し い課題や新しい産業へも注目していきたいと思います.

アナログからディジタルへ，そしてHDTVへという流 れが着実に社会に浸透してきました。家庭のテレビやム ービーまでもHDTVに移行してきました。これらは, 過 去数十年の本会を中心とした研究開発成果の積み上げで 築かれてきました.HDTVからさらに進んで“超臨場映 像” である超高精細や立体映像への技術開発も現在加速 しています。これまでもそうであったように，映像メデ イアの進化は, 社会的にも大きなライフスタイルの変化 を促進することでしょう．例えば，今まで充分に導入さ れてこなかったテレワークも, 䨌囲気まで伝える映像メ ディア技術で進むかもしれません.

何十年かの後に, 生活へ良い変化を生むことを期待し て, その種となる研究や話題を束ね, 魅力的な学会誌を 作り上げていきたいと思います。 